\title{
Inhibition of lard oxidation by fractions of different essential oils
}

\author{
By Tea Kulisic ${ }^{1 *}$, Ani Radonic ${ }^{2}$ and Mladen Milos ${ }^{1}$ \\ ${ }^{1}$ Department of Biochemistry and Food Chemistry, tea@ktf-split.hr (Tea Kulisic) \\ ${ }^{2}$ Department of Organic Chemistry. Faculty of Chemical Technology, University of Split, \\ Teslina 10/V, 21000 Split, Croatia
}

\begin{abstract}
RESUMEN
Inhibición de la oxidación de la manteca de cerdo por fracciones de diferentes aceites esenciales.

Se examinó la capacidad de los aceites esenciales de Origanum vulgare L. spp. hirtum, Thymus vulgaris L., Thymus serpyllum L., Satureja montana L. y Satureja cuneifolia Ten. para inhibir la oxidación de la manteca de cerdo pura. Excepto Satureja cuneifolia Ten., todos los aceites esenciales mostraron un acusado perfil fenólico caracterizado por la presencia de fenoles monoterpénicos- timol y carvacrol. El método Rancimat ha sido aplicado a manteca de cerdo sembrada con los aceites esenciales y sus fracciones. La capacidad de los aceites y sus fracciones para actuar como inhibidores de la oxidación de lípidos fue menor en comparación con la de antioxidante sintéticos (BHA y BHT), ácido ascórbico y $\alpha$-tocoferol. El efecto antioxidante de las sustancias ensayadas dependió de la dosis. El periodo de inducción de la manteca de cerdo pura no se afectó por la cantidad de muestra presente en el sistema de reacción.
\end{abstract}

PALABRAS-CLAVE: Aceite esencial - Antioxidante - Hierbas medicinales - Método de Rancimat - Oxidación de lípidos.

\section{SUMMARY}

Inhibition of lard oxidation by fractions of different essential oils.

The ability to inhibit lard oxidation by the essential oils of Origanum vulgare L. spp. hirtum, Thymus vulgaris L., Thymus serpyllum L., Satureja montana L. and Satureja cuneifolia Ten. was examined. Except Satureja cuneifoila Ten. essential oil, all the essential oils studied showed a strong phenolic profile characterized by the presence of phenolic monoterpenes - thymol and carvacrol. The Rancimat method has been applied on lard spiked with essential oils and their fractions. The ability of the essential oils tested and their fractions to act as inhibitors of the lipid oxidation process was lower in comparison with reference antioxidants (BHA and BHT), ascorbic acid and $\alpha$-tocopherol).

The antioxidant effect of the antioxidants tested was dose-dependent. Induction time of pure lard is not effected by the quantity of the oil sample in the reacting system.

KEY-WORDS: Antioxidant - Essential oil - Lipid oxidation Medicinal herbs - Rancimat method.

\section{INTRODUCTION}

The two most important types of chemical reactions responsible for quality loss in processed foods have been identified as browning and oxidation (Löliger, 1991). The process of lipid oxidation in foods is responsible for the formation of off-flavors and undesirable chemical compounds, which may be detrimental to health (Brand-Williams et al., 1995). The progression of oxidation in a food system occurs from the formation of radicals through primary oxidation products (lipid hydroperoxides) and secondary oxidation products (aldehydes and ketones) to protein damage.

Antioxidants may be active at different stages of the progression of oxidation in food systems. However, the conditions for which the different antioxidative mechanisms contribute to the protection of an actual food product are not well understood. The use of real food systems for detailed studies of antioxidants is complicated by a large number of factors, which are often unknown or cannot be controlled due to the complex nature of foods. Using simplified model systems, which mimic the main features of a given food system, or antioxidant assays for quantifying the antioxidant action, can be very helpful in clarifying the action of potential antioxidants (Andersen et al., 2002).

Because of market requirements, the use of synthetic antioxidants is being replaced more and more by natural antioxidants from plant sources. Many sources of antioxidants of plant origin have been studied in recent years and numerous types of antioxidants with varied activities were identified (Lagouri et al., 1993; Tsimidou and Boskou, 1994, Milos et al., 2000, Radonic and Milos, 2003). It has been clearly demonstrated in numerous model systems that plant phenolic compounds have antioxidative properties (Schwarz et al., 2001). Previous investigations proved the strong phenolic character of essential oils from oregano (Origanum vulgare L.) (Lagouri et al., 1993; Milos et al., 2000; Vichi et al., 2001), thyme (Thymus vulgaris L.) (Schwarz and Ernst, 1996), wild thyme (Thymus serpyllum L.) (Mailhebiau, 1994) and savory (Satureja montana L.) (Radonic and Milos, 2003). On the other hand, the Satureja cuneifolia essential oil (of Croatian origin) was found to contain a low percentage of phenolic compounds (Milos et al., 2001).

In this study we report the investigation of the ability of the previously mentioned herbs to inhibit the process of lard oxidation with essential oils in relation to their chemical composition. The Rancimat method was applied for these investigations because it mimics the process of lipid oxidation in a simple, 
reproducible and fast manner. The antioxidant effect of different essential oils and their fractions was evaluated in comparison with, the frequently used antioxidants (BHT, BHA, ascorbic acid and $\alpha$-tocopherol) and pure constituents thymol and carvacrol.

\section{EXPERIMENTAL}

\subsection{Materials}

The plant materials of oregano (Origanum vulgare L. spp. hirtum), thyme (Thymus vulgaris L.), wild thyme (Thymus serpyllum L.) and two savory species (Satureja montana L. and Satureja cuneifolia Ten.) were collected in Central Dalmatia (Croatia). Plant material (flower tops and stalks), after air-drying, was used for the isolation of the essential oils. A hundred grams of each dried plant material was subjected to a $3 \mathrm{~h}$ hydrodystillation using a Clevenger-type apparatus. The obtained essential oils were dried over anhydrous sodium sulphate and stored under nitrogen in a sealed vial at $-20{ }^{\circ} \mathrm{C}$ until needed. The voucher specimens of plant material as well as their essential oils are stored in the Department of Biochemistry and Food Chemistry, Faculty of Chemical Technology, Split, Croatia.

The essential oils of oregano, thyme, wild thyme and two savory species $(0.5 \mathrm{~g})$ were fractionated using a silica gel (30-60 $\mu \mathrm{m}$, Mallinckrodt Baker B.V., Deventer, The Netherlands) column (length $20 \mathrm{~cm}$; i.d. $2 \mathrm{~cm})$. Pentane $(50 \mathrm{~mL})$ was used to obtain a fraction, which contained only non-polar hydrocarbons ( $\mathrm{CH}$ fraction), and diethyl ether (50 $\mathrm{mL}$ ) was used to obtain a fraction of polar (oxygen containing, $\mathrm{CHO}$ fraction) compounds. These fractions were concentrated to $0.5 \mathrm{~mL}$ and subjected to thin layer chromatography (TLC) on silica gel plates in order to check results of the column chromatography separation. Different solvents were used as mobile phase: $n$-hexane for $\mathrm{CH}$ fraction and n-hexane:ethyl acetate 85:15 (v/v) for $\mathrm{CHO}$ fraction. Two percent vanillin-sulphuric acid was used as a detection reagent. The fractions obtained by column chromatography were also subjected to GC/MS analysis and good separation results were confirmed.

In order to obtain a fraction of phenolic compounds, $0.5 \mathrm{~g}$ of the essential oils from Origanum vulgare L. spp. hirtum, Thymus vulgaris L. and Satureja montana L. was dissolved in $5 \mathrm{~mL}$ pentane and extracted with sodium hydroxide solution (20\%) in water. In this manner, phenolic compounds were removed from the pentane layer. The aqueous phase, containing dissolved phenolic compound sodium salts, was neutralized with hydrochloric acid solution (10\%) in water. Finally, isolation of the phenolic compounds was performed by extraction with pentane $(5 \times 5 \mathrm{~mL})$. The effectiveness of this separation method was tested by TLC on silica gel plates (mobile phase: $n$-hexane:ethyl-acetate $85: 15 \mathrm{v} / \mathrm{v}$ ). Purity of the phenolic compounds fraction was confirmed by GC/MS analysis.

The lard applied in the Rancimat method was home made (free of added antioxidants or preservatives).

\subsection{GC-MS analysis}

The analyses of the volatile compounds were run on a Hewlett-Packard GC-MS system (GC 5890 series II; MSD 5971A, Hewlett Packard). The fused-silica HP-20 M polyethylene glycol column (50 $\mathrm{m} \times 0.2 \mathrm{~mm}, 0.2 \mu \mathrm{m}$ thickness, Hewlett-Packard) was directly coupled to the mass spectrometer. The carrier gas was helium $(1 \mathrm{~mL} / \mathrm{min})$. The program used was 4 min isothermal at $70{ }^{\circ} \mathrm{C}$, then $4{ }^{\circ} \mathrm{C} / \mathrm{min}$ to $180{ }^{\circ} \mathrm{C}$ and $10 \mathrm{~min}$ isothermal. The injection port temperature was $250^{\circ} \mathrm{C}$ and the detector temperature was $280^{\circ} \mathrm{C}$. Ionization of the sample components was performed in the El mode (70 eV).

The linear retention indexes for all the compounds were determined by co-injection of the sample with a solution containing the homologous series of $\mathrm{C}_{8}-\mathrm{C}_{22}$ $n$-alkanes (Van den Dool and Kratz, 1963). The individual constituents were identified by their retention indexes referring to the compounds known from literature data (Adams, 1995); and also by comparing their mass spectra with spectra of either the known compounds or with those stored in the Wiley mass spectral database (Hewlett-Packard).

\subsection{Induction period of lard oxidation (Rancimat method)}

The induction period of lard with and without the addition of antioxidants was determined with the Rancimat model 743 (Metrohm, Switzerland) at 100 ${ }^{\circ} \mathrm{C}$ and the airflow of $20 \mathrm{~L} / \mathrm{h}$. The ethanolic solutions of different concentrations of antioxidant $(100 \mu \mathrm{L})$ were added to the lard $(2.5 \mathrm{~g})$ giving a final concentration of $0.16 \%, 0.12 \%, 0.08 \%, 0.04 \%$ and $0.016 \%(\mathrm{w} / \mathrm{w})$ of the antioxidant in the reacting system.

The antioxidant activity index $(\mathrm{Al})$ is calculated from the measured induction times, according to the following formula by Forster et al. (2001).

\section{$\mathrm{Al}=$ Induction time of lard with antioxidant / Induc- tion time of pure lard}

Although this technique has been questioned (Frankel, 1993), it is a procedure commonly used in the food industry and governmental analytical laboratories (Parejo et al., 2003). 


\section{RESULTS AND DISCUSSION}

\subsection{Chemical composition of essential oils}

The chemical composition of total and fractionated essential oils from oregano, thyme and wild thyme is shown in Table I, while Table II show the chemical composition of the total and fractionated essential oil from two savory species, Satureja montana L. and Satureja cuneifolia Ten. Except Satureja cuneifolia Ten., all the essential oils showed qualitative similarities and a strong phenolic character.

In the essential oil of oregano eleven compounds were identified ( $97.9 \%$ of total oil) with phenolic monoterpenes thymol (35.0\%) and carvacrol $(32.0 \%)$ as the major compounds. Monoterpenic hydrocarbons $\gamma$-terpinene (10.5\%), p-cymene (9.1\%) and $\alpha$-terpinene $(3.6 \%)$ represented other important constituents of oregano essential oil (Kulisic et al., 2004). Similar results were already reported by Vokou et al. (1993).

Table I

The composition (area \%) of Origanum vulgare L. spp. hirtum, Thymus vulgaris L. and Thymus serpyllum L. essential oils

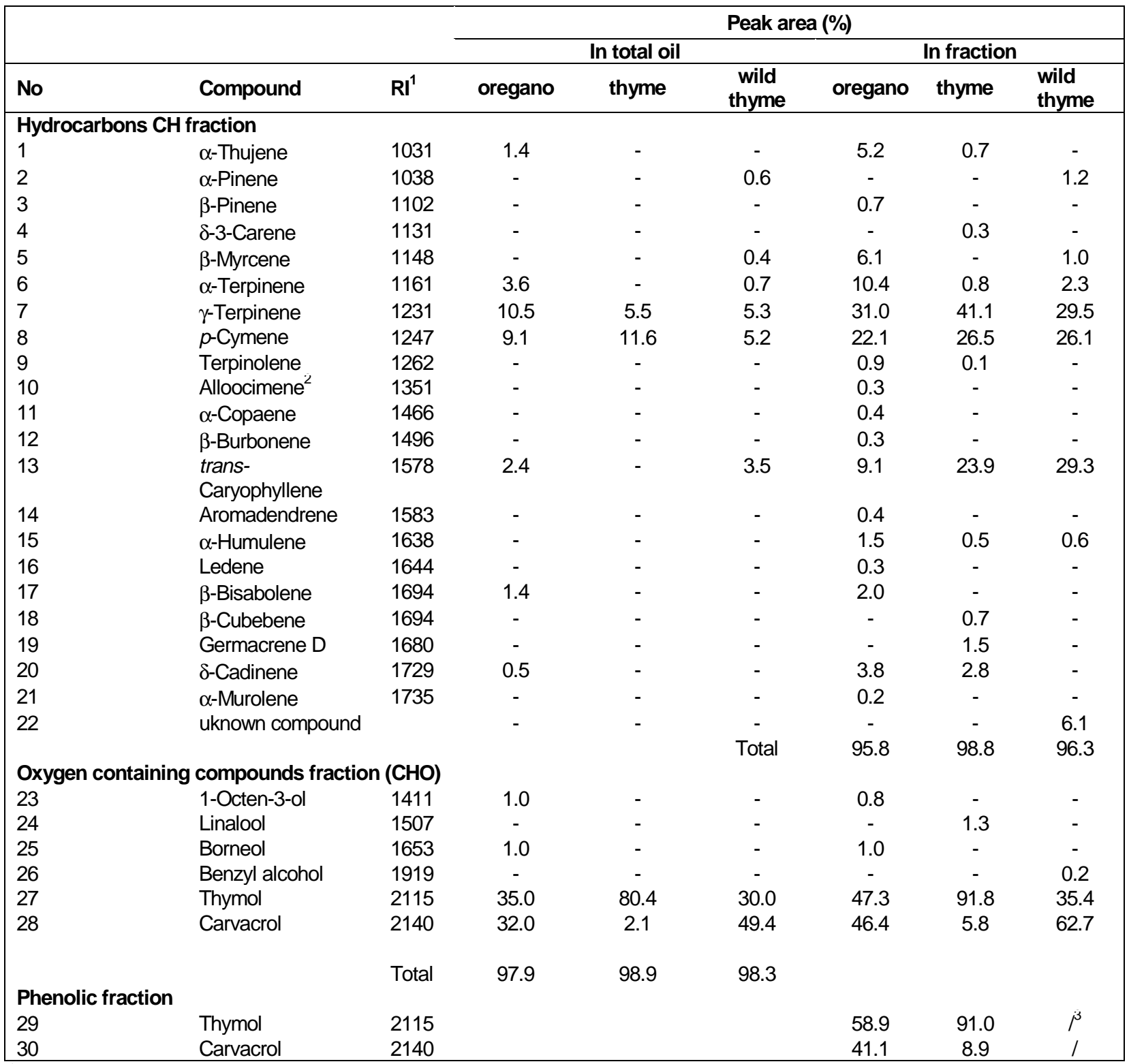

${ }^{1}$ Retention indices relative to C8-C22 alkanes on polar HP-20M column

${ }^{2}$ Correct isomer is not identified

${ }^{3}$ Phenolic fraction was not isolated 
Table II

The composition (area \%) of Satureja montana L. and Satureja cuneifolia Ten. essential oils

\begin{tabular}{|c|c|c|c|c|c|c|}
\hline \multirow[b]{3}{*}{ No } & \multirow[b]{3}{*}{ Compound } & \multirow[b]{3}{*}{$\mathbf{R I}^{1}$} & \multicolumn{4}{|c|}{ Peak area $(\%)$} \\
\hline & & & \multicolumn{2}{|c|}{ In total oil } & \multicolumn{2}{|c|}{ In fraction } \\
\hline & & & S. montana & S. cuneifolia & S. montana & S. cuneifolia \\
\hline \multicolumn{7}{|c|}{$\begin{array}{l}\text { Hydrocarbons } \mathrm{CH} \\
\text { fraction }\end{array}$} \\
\hline 1 & $\alpha$-Thujene & 1031 & 1.0 & - & 2.7 & - \\
\hline 2 & $\alpha$-Pinene & 1038 & 1.0 & 8.5 & 2.0 & 13.6 \\
\hline 3 & $\beta$-Pinene & 1102 & - & - & 2.1 & - \\
\hline 4 & Myrcene & 1149 & - & 1.6 & - & 3.2 \\
\hline 5 & $\alpha$-Terpinene & 1161 & 3.5 & - & 7.5 & - \\
\hline 6 & Limonene & 1179 & - & 2.7 & - & 4.3 \\
\hline 7 & cis- $\beta$-Ocimene & 1218 & - & 6.5 & - & 18.9 \\
\hline 8 & $\gamma$-Terpinene & 1231 & 5.9 & - & 19.8 & - \\
\hline 9 & trans- $\beta$-Ocimene & 1235 & - & 4.7 & - & 14.1 \\
\hline 10 & p-Cymene & 1247 & 6.4 & 1.3 & 23.1 & 2.3 \\
\hline 11 & Terpinolene & 1262 & - & - & 0.6 & - \\
\hline 12 & Alloocimene $^{2}$ & 1351 & 0.6 & 2.3 & 1.8 & 3.8 \\
\hline 13 & $\alpha$-Copaene & 1466 & - & - & 0.5 & - \\
\hline 14 & $\beta$-Burbonene & 1496 & - & - & 0.7 & - \\
\hline 15 & $\beta$-Cubebene ${ }^{4}$ & 1524 & - & - & 8.9 & - \\
\hline 16 & $\begin{array}{l}\text { trans- } \\
\text { Caryophyllene }\end{array}$ & 1578 & 2.3 & 1.1 & 18.2 & 6.9 \\
\hline 17 & $\alpha$-Humulene & 1638 & 0.3 & - & 1.3 & - \\
\hline 18 & Zingiberene & 1659 & - & - & 0.6 & - \\
\hline 19 & $\gamma$-Cadinene & 1677 & - & - & 0.4 & - \\
\hline 20 & Germacrene D & 1680 & - & 10.3 & - & 20.3 \\
\hline 21 & $\alpha$-Elemene & 1687 & 0.3 & - & 0.7 & - \\
\hline 22 & $\beta$-Bisabolene & 1694 & 1.1 & - & 3.1 & - \\
\hline 23 & $\delta$-Cadinene & 1729 & - & 1.7 & 2.3 & 4.7 \\
\hline 24 & $\alpha$-Murolene & 1735 & - & - & 0.2 & - \\
\hline & & & & Total & 96.5 & 92.1 \\
\hline \multicolumn{7}{|c|}{$\begin{array}{l}\text { Oxygen containing compounds } \\
\text { fraction (CHO) }\end{array}$} \\
\hline 25 & 1-Octen-3-ol & 1411 & 0.7 & - & 0.8 & - \\
\hline 26 & $\begin{array}{l}\text { trans-Sabinene } \\
\text { hydrate }\end{array}$ & 1423 & 0.2 & - & 0.3 & - \\
\hline 27 & Linalool & 1507 & 0.6 & 29.3 & 0.7 & 62.0 \\
\hline 28 & $\begin{array}{l}\text { Thymol methyl } \\
\text { ether }\end{array}$ & 1563 & 5.1 & 2.7 & 4.4 & - \\
\hline 29 & $\begin{array}{l}\text { Carvacrol methyl } \\
\text { ether }\end{array}$ & 1576 & 5.8 & 2.3 & 6.6 & 3.2 \\
\hline 30 & Neral & 1641 & - & - & 0.2 & - \\
\hline 31 & Borneol & 1653 & 3.9 & 3.9 & 4.7 & 7.4 \\
\hline 32 & Geranial & 1680 & - & -- & 0.5 & - \\
\hline 33 & Geranyl acetate & 1729 & 2.1 & - & 2.2 & - \\
\hline 34 & Nerol & 1752 & 1.1 & - & 1.2 & - \\
\hline 35 & Geraniol & 1796 & 5.0 & - & 6.2 & - \\
\hline 36 & 3-Phenylpropanol ${ }^{4}$ & 1947 & - & - & 0.2 & - \\
\hline 37 & Thymol & 2115 & 45.2 & 8.9 & 61.6 & 9.4 \\
\hline 38 & Carvacrol & 2140 & 5.3 & 4.0 & 7.1 & 4.8 \\
\hline \multirow{2}{*}{\multicolumn{7}{|c|}{ Phenolic fraction }} \\
\hline & & & & & & \\
\hline 39 & Thymol & 2115 & & & 85.5 & $\beta^{3}$ \\
\hline 40 & Carvacrol & 2140 & & Total & 14.5 & l \\
\hline
\end{tabular}

${ }^{1,2,3}$ as in Table I. ${ }^{4}$ Tentatively identification on basis of the mass spectra (MS) only 
Only four compounds were identified in thyme essential oil without fractionation: $\gamma$-terpinene $(5.5 \%)$, p-cymene $(11.6 \%)$, thymol $(80.4 \%)$ and carvacrol $(2.1 \%)$. In the essential oil from wild thyme eight compounds were identified with $p$-cymene $(5.2 \%)$, $\gamma$-terpinene $(5.3 \%)$, thymol $(30.0 \%)$ and carvacrol $(49.4 \%)$ as main components.

In the oregano essential oil seventeen compounds were identified in hydrocarbon $(\mathrm{CH})$ fraction with $\gamma$-terpinene $(31.0 \%)$, $p$-cymene $(22.1 \%)$, $\alpha$-terpinene $(10.4 \%)$ and trans-caryophyllene $(9.1 \%)$ as main components. The fraction with oxygencontaining compounds $(\mathrm{CHO})$, was represented by four compounds, with thymol (47.3\%) and carvacrol (46.4\%) as the major ones (Kulisic et al., 2004).

After fractionation, eleven compounds were identified in thyme hydrocarbon fraction where $\gamma$-terpinene $(41.1 \%), p$-cymene $(26.5 \%)$ and transcaryophyllene $(23.9 \%)$ were main components. The analysis of the wild thyme hydrocarbon fraction showed that it consists of eight compounds with $\gamma$-terpinene (29.5\%), p-cymene (26.1\%) and trans-caryophyllene $(29.3 \%)$ as main components. The fractions with oxygen-containing compounds in thyme and wild thyme essential oils, were represented by two phenolic compounds - thymol $(91.8 \%$ in thyme, $35.4 \%$ in wild thyme) and carvacrol (5.8\% in thyme, $62.7 \%$ in wild thyme) as the major compounds.

As shown in Table II the phenolic monoterpene thymol $(45.2 \%)$ was also found to be the main constituent of the essential oil of Satureja montana L. The presence of monoterpenic hydrocarbons $p$-cymene $(6.4 \%)$ and $\gamma$-terpinene $(5.9 \%)$ and oxygen-containing compounds carvacrol methyl ether $(5.8 \%)$, thymol methyl ether $(5.1 \%)$, carvacrol $(5.3 \%)$, geraniol $(5.0 \%)$ and borneol (3.9\%) represented the other constituents of this essential oil (Radonic and Milos, 2003). On contrary, the essential oil of Satureja cuneifolia Ten. contained a low percentage of thymol (8.9\%) and carvacrol (4.0\%). Linalool (29.3\%) and germacrene D (10.3\%) were the main components of this essential oil.

After fractionation, in the essential oil of Satureja montana L. nineteen compounds were identified in hydrocarbon fraction with $p$-cymene $(23.1 \%)$, $\gamma$-terpinene $(19.8 \%)$, trans- caryophyllene $(18.2 \%)$ and $\beta$-cubebene $(8.9 \%)$ as main components. The fraction with oxygen-containing compounds, which consisted of fourteen compounds, was dominated by thymol $(61.6 \%)$ and the other important components were carvacrol $(7.1 \%)$, carvacrol methyl ether $(6.6 \%)$, geraniol $(6.2 \%)$, borneol $(4.7 \%)$ and thymol methyl ether (4.4\%) (Radonic and Milos, 2003). Quite different results were obtained from the fractionation of Satureja cuneifolia Ten. essential oil. Hydrocarbon fraction consisted of ten compounds with germacrene D (20.3\%), cis- $\beta$-ocymene $(18.9 \%)$, trans- $\beta$-ocymene (14.1\%) and $\alpha$-pinene $(13.6 \%)$ as main components. Among five compounds in the oxygen-containing fraction, linalool $(62.0 \%)$ was the highly dominating compound.

\subsection{Inhibition of lard oxidation (Rancimat method)}

The autoxidation of lipids can be inhibited or retarded by adding different antioxidants. They function either by scavenging chain-carrying peroxyl radicals or by diminishing the formation of initiating lipid radicals (Yamamoto and Niki, 1990). The mechanism of the antioxidant action of phenolic antioxidants in lipids has not been completely explained so far (Yanishlieva et al., 1999).

Table III shows the induction times of lard in the presence of the total essential oils and their fractions from oregano, thyme, wild thyme and two savory species in comparison with reference antioxidants (BHT, BHA, $\alpha$-tocopherol and ascorbic acid) and pure compounds thymol and carvacrol. The concentration of tested ethanolic solutions of antioxidants, which were added to the lard, was $0.16 \%(w / w)$. The inhibitory effect of the samples is expressed as the antioxidant activity index (Al).

The higher induction period of the lard with antioxidant added, compared to the control (pure lard) means improved antioxidant activity of that compound (von Gadow et al., 1997).

Reference compounds, BHA and $\alpha$-tocopherol, were the most potent inhibitors of the autoxidation of lipids with antioxidant activity indexes of 7.2 and 6.3. Synthetic antioxidant BHA has already been approved to control lipid oxidation in foods (Imaida et al., 1983; Okada et al., 1990; Ayar et al., 2001), while $\alpha$-tocopherol is known as the main protection factor in a system like LDL, low-density lipoproteins (Jia et al., 1998; Zhu et al., 1999; Andersen et al., 2002). Ascorbic acid also showed a potent inhibitory effect against the autoxidation of lipid ( $\mathrm{Al}=4.3$ ). It is known that it is used in patented protection systems for lard and marine oils (Löliger, 1991). Among the reference compounds, BHT showed the lowest antioxidant activity index (3.6), which can be explained by its volatility at the high temperature of the test $\left(100^{\circ} \mathrm{C}\right)$ so BHT could rapidly sweep from the lipid (von Gadow et al., 1997).

In comparison with reference antioxidants, the total essential oils tested and their fractions showed a poor inhibitory effect against the lard autoxidation process under the conditions of this method, but very similar to those obtained for pure thymol and carvacrol. Among the essential oils tested the longest induction time for lard was achieved by the addition of oregano essential oil $(\mathrm{Al}=2.0)$. Results for the other tested essential oils decreased in the order Thymus vulgaris L.> Thymus serpyllum L.> 
Table III

Induction times of lard and the antioxidant activity index (AI) of various antioxidants determined by the Rancimat method

\begin{tabular}{|c|c|c|}
\hline Antioxidant ${ }^{1}$ & Induction time (h) & Al \\
\hline \multicolumn{3}{|l|}{ Total essential oils } \\
\hline Origanum vulgare L. spp. hirtum & 10.2 & 2.0 \\
\hline Thymus vulgaris $\mathrm{L}$. & 9.0 & 1.7 \\
\hline Thymus serpyllum L. & 7.9 & 1.5 \\
\hline Satureja montana L. & 6.8 & 1.3 \\
\hline Satureja cuneifolia Ten. & 4.4 & 0.8 \\
\hline \multicolumn{3}{|l|}{ Hydrocarbons $\mathrm{CH}$ fraction } \\
\hline Origanum vulgare L. spp. hirtum & 5.3 & 1.0 \\
\hline Thymus vulgaris $\mathrm{L}$. & 4.4 & 0.8 \\
\hline Thymus serpyllum L. & 4.0 & 0.7 \\
\hline Satureja montana L. & 5.5 & 1.0 \\
\hline Satureja cuneifolia Ten. & 0.6 & 0.1 \\
\hline \multirow{2}{*}{\multicolumn{3}{|c|}{$\begin{array}{l}\text { Oxygen-containing compounds } \\
\text { fraction (CHO) }\end{array}$}} \\
\hline & & \\
\hline Origanum vulgare L. spp. hirtum & 8.0 & 1.5 \\
\hline Thymus vulgaris $\mathrm{L}$. & 10.2 & 2.0 \\
\hline Thymus serpyllum L. & 7.2 & 1.4 \\
\hline Satureja montana L. & 6.9 & 1.3 \\
\hline Satureja cuneifolia Ten. & 6.3 & 1.2 \\
\hline \multicolumn{3}{|l|}{ Phenolic fraction } \\
\hline Origanum vulgare L. spp. hirtum & 6.9 & 1.3 \\
\hline Thymus vulgaris $\mathrm{L}$. & 8.3 & 1.6 \\
\hline Satureja montana L. & 7.3 & 1.4 \\
\hline$\overline{\mathrm{BHT}}$ & 19.8 & 3.6 \\
\hline BHA & 37.8 & 7.2 \\
\hline$\alpha$-Tocopherol & 35.4 & 6.3 \\
\hline Ascorbic acid & 22.5 & 4.3 \\
\hline Thymol & 7.7 & 1.5 \\
\hline Carvacrol & 7.2 & 1.4 \\
\hline
\end{tabular}

${ }^{1}$ Concentration of tested antioxidant, which was added to the lard was $0.16 \%(\mathrm{w} / \mathrm{w})$ in reacting system

The induction time of pure lard was $5.2 \mathrm{~h}$.

Satureja montana L.>Satureja cuneifolia Ten. Thymol and carvacrol, which were the main components of essential oils of Origanum vulgare L. spp. hirtum, Thymus vulgaris L., Thymus serpyllum L. and Satureja montana L., can be effective in the inhibition of lard autoxidation at $35{ }^{\circ} \mathrm{C}$ at a concentration of $0.1 \%$ (Lagouri et al., 1993). Lagouri and Boskou (1996) concluded that the inhibition of oxidation by the essential oils from plants of the oregano species was highly dependent on the content of carvacrol and thymol. However, results presented in this study proved the opinion established by Yanishlieva et al. (1999) concerning the volatilities of thymol and carvacrol at $100{ }^{\circ} \mathrm{C}$, which is the main reason for their relatively low inhibitory effect observed by this method. The essential oil from Satureja cuneifolia 
Table IV

Induction times of the lard with the addition of increasing amounts of various antioxidants determined by the Rancimat method

\begin{tabular}{llccr}
\hline Total essential oil & \multicolumn{4}{c}{ Concentration (\%) } \\
& $\mathbf{0 . 0 1 6}$ & $\mathbf{0 . 0 4}$ & $\mathbf{0 . 0 8}$ & $\mathbf{0 . 1 2}$ \\
\hline & & \multicolumn{4}{c}{ Induction time (h) } \\
\cline { 3 - 5 } Origanum vulgare L. spp. hirtum & 5.8 & 7.0 & 7.6 & 10.6 \\
Thymus vulgaris L. & 6.6 & 7.1 & 8.5 & 9.7 \\
Thymus serpyllum L. & 5.1 & 6.6 & 7.7 & 8.5 \\
Satureja montana L. & 5.1 & 5.4 & 5.9 & 6.1 \\
\hline
\end{tabular}

The induction time of pure lard was $5.2 \mathrm{~h}$.

Ten. showed the poorest inhibitory effect probably because of the non-phenolic character of this oil.

The inhibitory effect of oxygen-containing compound fractions $(\mathrm{CHO})$ was very similar to those for essential oils. Oxygen-containing compound fraction from Thymus vulgaris $\mathrm{L}$. showed the longest induction time $(\mathrm{Al}=2.0)$. Almost all $\mathrm{CH}$ fractions showed a prooxidative effect $(\mathrm{Al}<1)$, except Origanum vulgare L. spp. hirtum and Satureja montana $\mathrm{L}$. $\mathrm{CH}$ fractions with $\mathrm{Al}=1$. The strongest prooxidative effect showed $\mathrm{CH}$ fraction from Satureja cuneifolia Ten. $(\mathrm{Al}=0.1)$, which could be the reason for the lower Al value of the total oil in comparison to the $\mathrm{Al}$ value of the $\mathrm{CHO}$ fraction of this oil. Phenolic fractions from Origanum vulgare L. spp. hirtum, Thymus vulgaris L. and Satureja montana L., consisted of thymol and carvacrol (Table I and II), and exhibited lower inhibitory effect in comparison to the effect of oxygen-containing compound fractions, which continues the speculations about the sinergy among minor oxygen containing compounds (Janssen et al., 1988, Kulisic et al., 2004).

The results presented in Table IV prove that the antioxidant effect of tested essential oils was dose-dependent. The induction times of lard were not affected by the different quantity of lard ( $5.2 \mathrm{~h}$ was induction time for $2.0 \mathrm{~g}, 2.5 \mathrm{~g}$ and $3.0 \mathrm{~g}$ of lard).

Since the conditions of this test were extreme (temperature $-100{ }^{\circ} \mathrm{C}$ and air flow - $20 \mathrm{~L} / \mathrm{h}$ ), the volatile nature of tested antioxidants reduces their inhibitory effect in the lard autoxidation process. However, due to their strong phenolic character, the essential oils of the herbs tested could find their use in food protection, mostly in food processing at lower temperatures or in the process of food storage.

\section{ACKNOWLEDGEMENTS}

This work was supported by the Ministry of Science, Education and Sport of the Republic of Croatia, Projects 0011-003 and HITRA TP-011701.

\section{BIBLIOGRAPHY}

Adams, R.P. (1995). Identification of essential oil components by gas chromatography and mass spectroscopy. Carol Stream, IL: Allured Publ.

Andersen, M.L., Lauridsen, R.K. y Skibsted, T.M. (2002). Optimising the use of phenolic compounds in foods in Pytochemical Functional Foods p.315-340. Johnson, I. y Williamson, G. (Ed.), Woodhead Publishing Limited.

Ayar, A., Ozcan, M., Akgul, A. y Akin, N. (2001). Butter stability affected by extracts of sage, rosemary and oregano. J. Food Lipids 8, 15-25.

Brand-Williams, W., Cuvelier, M.E. y Berset, C. (1995). Kinetics and mechanisms of antioxidant activity using the DPPH free radical method. Lebensm. Wiss. Technol. 28, 609-615.

Forster, A., Simon, K., Schmidt, R. y Kaltner, D. (2001). What is about antioxidative characteristics of hops? 28. EBC-Congress, Budapest.

Frankel, E.N. (1993). In search of better methods to evaluate natural antioxidants and oxidative stability in food lipids. Trends Food Sci. Technol. 4, 220-225.

Imaida, K., Fukishima, S., Shirai, T., Ohtami, M., Nakamish, K. y Ito, N. (1983). Promoting activites of butylated hydroxyanisole and butylated hydroxytoluene on 2-stage urinary bladder carcinogenesis and inhibition of gammaglutamyl trans-peptide-positive for development in the liver of rats. Carcinogenesis 4, 985-899

Janssen, A.M., Tsai, Ribe, W.H.R., Scheffer, J.J.C. y Baerheim Svendsen, A. (1988). Citronellal and citronellol, a case of antimicrobial anatgonism? Flavour Frag. J. 3, 137-140.

Jia, Z.S., Zhou, B., Yang, L., Wu, L.M. y Liu, Z.L. (1998). Antioxidant synergism of tea polyphenols and $\alpha$-tocopherol against free radical induced peroxidation of linoleic acid in solution. J. Chem. Soc. Perkin. Trans. 2, 911-915.

Kulisic, T., Radonic, A., Katalinic, V. y Milos, M. (2004). Use of different methods for testing antioxidative activity of oregano essential oil. Food Chem. 85, 633-640.

Lagouri and Boskou (1996). Nutrient antioxidants in oregano. Int. J. Food. Sci. Nutr. 47, 493-497.

Lagouri, V., Blekas, G., Tsimidou, M., Kokkini, S.y Boskou, D. (1993). Composition and antioxidant activity of essential oil from Oregano plants grown in Greece. Lebensmitt.-Unters. Forsch. 197, 20-23.

Löliger, L. (1991). The use of antioxidants in foods in Free Radicals and Food Additives, p. 121-150. Aruoma, O.I. y Halliwell, B. (Ed.), Taylor and Francis, London. 
Mailhebiau, P. (1994). La nouvelle aromathérapie. $2^{\mathrm{è}}$, Edition Vie Nouvelle, 133-142.

Milos, M., Mastelic, J. y Jerkovic, I. (2000). Chemical composition and glycosidically bound volatile compounds from oregano (Origanum vulgare L. spp. hirtum) Food Chem. 71, 79-83.

Milos, M., Radonic, A., Bezic, N. y Dunkic, V. (2001). Localities and seasonal variations in the chemical composition of essential oils of Satureja montana L. and S. cuneifolia Ten. Flavour Fragr. J. 16, 157-160.

Okada, Y., Okajima, H., Konoshi, H., Terauchi, M., Ishii, K., Liu, I.M. y Watanabe, H. (1990). Antioxidant effect of naturally occurring furan fatty acids on oxidation of linoleic acid in aqueous dispersion. J. Am. Oil Chem. Soc. 67, 858-862.

Parejo, I., Viladomat, F., Bastida, J., Rosas-Romero, A., Saavedra, G., Murcia, M.A., Jimenez., A.M. y Codina, C. (2003). Investigation of Bolivian plant extracts for their radical scavenging activity and antioxidant activity. Life Sci. 73, 1667-1681.

Radonic, A. y Milos, M. (2003). Chemical composition and in vitro evaluation of antioxidant effect of free volatile compounds from Satureja montana L. Free Rad. Res. 37, 673-679.

Schwarz, K. y Ernst, H. (1996). Evaluation of antioxidative constituents from thyme. J. Sci. Food Agric. 70, 217-223.

Schwarz, K., Bertelsen, G., Nissen, L.R., Gardner, P.T., Heinonen, M., Hopia, A., Huynh-Ba, T., Lamnelet, P., McPhail, D., Skibsted, L.H. y Tijburg, L. (2001). Investigation of plant extracts for the protection of processed foods against lipid oxidation. Comparison of antioxidant assays based on radical scavenging, lipid oxidation and analysis of the principal antioxidant compounds. Eur. Food Res. Technol. 212, 319-328.

Tsimidou, M. y Boskou, D. (1994). Antioxidant activity of essential oils from plants of the Lamiaceae family. In
Spices, Herbs and Edible Fungi, p. 273-284. Charalambous, G. (Ed.), Elsevier Science B.V.

Van den Dool, H. y Kratz, P.D. (1963). A generalization of the retention index system including linear temperature programmed gas-liquid partition chromatography. $J$. Chromatogr. 11, 463-471.

Vichi, S., Zitterl-Eglseer, K., Jugi, M. y Fraz, C. (2001). Determination of the presence of antioxidants deriving from sage and oregano extracts added to animal fat by means of assessment of the radical scavenging capacity by photochemiluminiscence analysis. Nahrung-Food 45, 101-104.

Vokou, D., Kokkini, S. y Bessiere, J.M. (1993). Geographic variation of Greek oregano (Origanum vulgare spp. hirtum) essential oils. Biochem. System. Ecol. 21, 287-295.

Von Gadow, A., Joubert, E. y Hansmann, C.F. (1997). Comparison of the antioxidant activity of aspalathin with that of other plant phenols of Rooibos Tea (Aspalathus linearis), $\alpha$-tocopherol, BHT and BHA. J. Agric. Food Chem. 45, 632-638.

Yamamoto, Y. y Niki, E. (1990). Role of antioxidants in lipid peroxidation in Membrane Lipid Oxidation. Vigo-Pelfrey, C. (Ed.) CRC Press, Boca Raton, Florida.

Yanishlieva, N.V., Marinova, E.M., Gordon, M.H. y Raneva V.G. (1999). Antioxidant activity and mechanism of action of thymol and carvacrol in two lipid systems. Food Chem. 64, 59-66.

Zhu, Q.Y., Huang, Y., Tsong, D. y Chen, Z.Y. (1999) Regeneration of $\alpha$-tocopherol in human low-density lipoprotein by green tea catechin. J. Agric. Food Chem. 47, 2020-25. 